\title{
THE TRANSLATION OF SYMPTOMS INTO THEIR MECHANISM.*
}

\author{
By CHESTER L. CARLISLE, M. D., \\ Senior Assistant Physician, Kings Park State Hospital, \\ Kings Park, L. I., N. Y.
}

The foundation of the concept that all our conduct and utterance, whether considered normal or abnormal, is based on underlying subconscious trends of direction, is comparatively modern, particularly in its clinical application. The literature on psychoanalytical investigation is quite ample and the case-records sufficiently convincing to warrant our earnest attention.

In this paper I do not attempt to add cases adducing new and positive testimony to the value of psycho-analysis, but rather to accept as axiomatic that the "why" of a person's conduct and utterance depends upon the "because" of underlying complexes, all linked in many ways with each other, and thus reaching back into early infantile psychic beginnings as continuously and surely as the progress of the lifetime itself.

Assuming then that the everyday life of the adult is dependent upon subconscious complexes of affect value, the dynamic value of which is determined largely in the infantile period, it seemed to me worth our while to determine by similar methods just what complexes were of most significant value in our patients' lives. The main trend of all our lives shaped from infantile ruminations, developing upon the soil of individual personality with its possibilities of neuropathic non-resistance and further subject to the strains of environment, must after all finally center toward some one great wish above all others. Almost invariably this seems to be found more or less closely associated with our sexual longings. If the wish is unattainable, we may bury it in the subconscious (where lie also those things we dare not face) and yet utilize the affect value in work for the world; or we may meet the facts frankly and consciously and attain the wish at any cost; or again

* Read at the seventieth annual meeting of the American Medico-Psychological Association, Baltimore, Md., May 26-29, 1914. 
we may be unable longer to bear the facts of life as they are and so retreat into a psychosis.

The analysis of cases from this latter group reveals the unknown affect complex which precipitated the essential conflict of the patient's life.

L. E. D. No. 74423.

Family History.-Complete for three generations. Maternal grandmother epileptic. Mother epileptic. One maternal uncle arteriosclerotic; died of apoplexy. Father neurasthenic type.

Personal History.-Born in New York State in I880; early childhood uneventful; no convulsions. Graduated from normal school; learned easily and was never left back in classes. Make up quantitatively normal; qualitatively was never very social in tendency, but later was forced to be so as a clergyman's wife; was always sensitive and worrisome, but seemed to be aggressive and did not drift much. No particular change in character after puberty and seemed normal up to time of marriage in 1905. She never had any children and no miscarriages. Had rather high ideals as to care of children and said she would never bring any into the world until she had the means of bringing them up as they ought to be. After marriage it was noticed that she would worry over small matters and if anyone in her husband's congregation acted indifferently she would refer it back to herself in some way. Before marriage her husband had known a Miss Hazard and patient always seemed jealous of this woman. On one occasion made a scene over her because her husband had arranged to have her appear on a programme. This woman appeared only once or twice in the patient's life, and apparently in quite an incidental way, but she always seemed to irritate her. She began to nag her husband more and more and for this reason he gave up pastoral work and moved to a farm. There the patient worked hard and not being associated with other people seemed to get along better. Finally they moved to a small town in I9II, where she had a horse and carriage and drove a great deal and some young men commented upon this. A Mr. Donovan worked in a store where she traded and she thought people made remarks concerning him and herself. In June, 1913, she rather suddenly became very unreasonable; would not allow her husband to light a fire and said, "If you do I will put it out." Began to talk about black and white influencing her; became angry over little things, and at last accused her husband of infidelity, and later, quite unreasonably, wanted him to take a trip to Syracuse, and when he refused to do this she took an axe and followed him around the yard with it. For these reasons she was committed.

On admission to Kings Park State Hospital March 31, 1914: Physically, neurologically negative. Mentally, quiet, compliant, spontaneous production normal in amount. Replies to questions relevant and coherent. General mental attitude consisted of a feeling that she had been talked about in an improper way, but accepted the situation pretty well and was fairly complaisant. Mood is one of mild depression with a feeling of dissatisfac- 
tion. Delusions of a persecutory type. Said, "I think I am as notorious as Harry Thaw. I have so much on my mind; I don't know what to say. When we went to Melville to live-two years ago-it commenced. One day I went to the village with my husband and while I sat in the wagon this young man came to the door and I bowed to him; he made motions as though he wanted to be intimate with me; I thought a great deal about him. I thought he wanted to see what kind of woman I was." She found that people knew all about her through the newspapers and pictures and by the day of the week on which they called on her, each day having a special meaning and lending color to their visits. Hallucinations were not demonstrable. Orientation and general mental organization intact. No gross deterioration. Insight partial, realizes the peculiarity of her ideas to some extent, but does not grasp their real significance.

Asked to make free associations, she showed that all her present ideas were related by direct association to a conflict which was based primarily upon the fact that she had never had her wish for children gratified and that she viewed her husband in the light of a man who was not prepossessing physically and who did not support her very well financially, and therefore was a person not particularly acceptable to her. Secondarily to this appears Mr. Donovan as the man whom she desired. She seems to have progressed quite normally through puberty and young adult life. After graduating she was an efficient school teacher, but after marrying her husband things began to go badly. He did not get along well in his church work and consequently they were financially unable to have children. She was jealous of Miss Hazard, whom her husband had taken out in a boat on one occasion previous to his marriage with the patient, and she said, "I carry that on my mind all the time." After her husband's failure as a minister they took up farm life and there she met Mr. Donovan in a store. On one occasion she asked in the store for lard and there was a great deal made over that by the other people. "This was because lard referred back to the last syllable of the name Hazard." The people thought that her asking for this lard referred to this girl. "They thought that I wanted her; that she was my daughter and I wanted her. They thought I was in a hurry. Hurry means Her-ry; another meaning, it was passive and I was working and selling things for my daughter." People whistled at the patient. "Whistling was masculine possessive-that brought me out of the hurry I have been in for so long. The whistling meant act-act 
in character-act, that refers to act in action-I was lonesome. I thought maybe (Donovan) could give me something that might make me feel better-act-I told him I didn't want my character hurt- Away back to the time when I had typhoid fever (age of 13) boy was white and girl was black-they thought because the little white-man was my character, I wanted him because I kept on trading there-I had a vaginal discharge-the whites, I haven't had it since.-I liked White." (White was the name she gave to the man in the store.) Later said, "The people wanted to get something on my mind-a boy off my mind-white represents a boy and the girl is black. They thought they would get something on my mind. What was on my mind was that I wanted a baby. I told the doctor I didn't feel like opening my mouth so my husband went and told what I wanted-later the trees had been cut from our farm-they thought I didn't like so much sunthat refers to son-because I was hot. That refers back to sexual things-back to the time when I had typhoid fever-you know how hot and feverish you are when you have that-Later people seemed to think that I had my husband on the left and an animal or a billy goat on the right-that means big to my right and little on my left. This young man was the billy goat. Now I am risen on the right and down on the left-I have risen on the left and now I am quite smart-the clipping in the paper was a little verse about 'Willie, Willie in a long tailed coat'-that makes me think of billy goat-they thought I had a young man on my mind-billy goat is the young man in the store." White is associated with a vaginal discharge which she had and she says "I always had a scent about me. Scent or cent-now they have taken that away from me-I have never wanted to work. I wanted to live in ease and luxury and have lots of love. I always did want lots of love and I want it yet-I had always been young and sweet-I regret that $I$ am old and have an old man on my mind. The whistle (she heard) meant that it was the possessive-the man possessive - the man possessed me and I possessed him. I would have been satisfied with my husband if we had had children." Dreams: "I saw the sky and then a large building-it looked like the Capitol of Washington. On the dome in large letters was the word Perfection." Analysis shows that Capitol refers to Mr. Cappelle. Washington to George-George Capelle. This re- 
fers back to George Allen, who is associated in the patient's mind with Mr. Donovan, the young man in the store, because he looked like George Allen. The word "perfection" means "perfection at last, we will all get it." (What we want.)

It is found also that the patient's unexplained desire to make a trip to Syracuse was because this town was much nearer to Mr. Donovan than Brooklyn. She apparently wished her husband to accompany her in order to cloak the underlying subconscious wish to get nearer the man she wanted and to make the trip appear quite conventional. There are many other associations in this case, but they all lead back to the primary conflict in her life. Superficially she presents simply the appearance of an ordinary case of dementia præcox, paranoid form, with a number of odd utterances which are quite incoherent and irrelevant on the surface, but upon analysis show continuous associations leading back to her desire for a child and dissatisfaction with her husband.

A. M., No. 72026.

Family History.-Complete for three generations. Sister and brother insane. One other brother alcoholic.

Personal History.-Born in Norway, I889; school record average, but did not thoroughly grasp subjects taught; ability for calculation above elementary exercises limited ; mental dexterity normal ; always seclusive, but still inclined to be fairly sociable. She came to America when 20 years of age; married and was a good housekeeper. She and her husband were purchasing a house on the instalment plan; his habits were good and on the surface everything seemed comfortable in their married life. In August, I913, three months previous to admission to Kings Park State Hospital, rather suddenly one night she began to talk peculiarly, saying, "I don't know what is the matter with my father and mother-they have tried to hang themselves." (They were in Norway.) A few days later she got up in the night and said she was dying, became apprehensive, made contradictory statements and on a later night the husband found her looking at him while in bed and she told him she thought he was dying. Following this, she imagined that everyone was down on her, stated that she felt afraid to stay alone in the house and felt impelled to rush out into the open air.

On admission to Kings Park State Hospital November I, 1913: Physically, was neurologically negative except for complaints of feeling of pins and needles in her back and a feeling of stiffness. Mentally, she was quiet and compliant. Stream of thought was relevant and coherent without formal disorder, but she discussed her case in an unsatisfactory way; denied hallucinations, but said she dreamed that all her family were going to be killed. Her attitude seemed rather apprehensive and she complained 
TRANSLATION OF SYMPTOMS INTO THEIR MECHANISM [Oct.

of a peculiar feeling in her throat which she described as a feeling of electricity, and when she feels this sensation she imagines that her husband is dead. Emotional tone was shallow, but there was a fairly natural affect; several times became emotional and shed tears. Asked to write, wrote her maiden name and when reminded of the mistake became embarrassed. Her personality seemed to have suffered a slump, became untidy and careless in her appearance and destroyed articles of clothing. She ceased worrying over her husband, never mentioned her baby and spoke of going home only in any offhand way. Finally in this condition she was deported to Norway.

Probing and free associations brought out the following conflict which was apparently the rock upon which her life made shipwreck: As a child she seemed to get along in an average way, but found that what she learned did not stick very well and she was inclined to drift. She got along very well with her brothers and sisters, but never confided in them particularly and although she liked to go out with companions as a young girl, yet kept her own affairs to herself. When she was about 16 she had her first lover. Said, "I had a fellow in Norway before this fellow I married. I went with the first fellow a year. I had no room to take him in as my bed was in the kitchen where the rest of the family slept; he always wanted to get me alone, but I would always take my girl friend with me. When he came to this country (the man left her in Norway and came to America) his face was all scratched up and I would not go down to the boat to see him off and after that he never wrote me any letters. That was in 1906. I came to this country in February, 1907, and married my man after only three days knowing him. I had been with him a couple of times and later I thought I was in the family way by him. I would not have married him if I had not been in the family way by him. My brother's wife saw my first fellow and he came to the house, but she would not tell me because I was going with Charlie (husband). In I910, after I was married, I went home to Norway and there I saw the first fellow. He talked like a fool-said he was going to drink and jump in the water (for love of the patient) - said he had a girl in the family way then and she had no home-and I told him to marry her and he did-I felt kind of bad when I seen him."

After the patient returned to the United States the second time from her visit to Norway she had given up her lover, as she had 
told him to marry another girl, but she always thought about him a great deal and always with a certain amount of longing. Essentially it seemed that he was the man whom she wanted for marriage (her wish), and after this affair was broken off because she would not go out with him when he wanted coitus, she wrote him letters which he did not answer and then she came to the United States, and began to have intercourse with Charlie (her husband), but she says she would not have married him if she had not become accidentally pregnant by him; then a miscarriage was induced (but she did not worry over this as it was a desired thing). She married and a child was born in October, 1909, and died 18 months later of spinal meningitis. A second child was born in November, 1912, and the patient was glad to have this baby, so she said, and was all right mentally until she went to live in the country about June, 1913. There she was alone a good deal while her husband commuted to the city. Strange ideas began to come to her "that everybody was dead." She saw a cartoon in the paper and thought the figure was that of her father and interpreted it as being that her father was in jail. She had a fear of the inside of the house and wanted to be on the outside, which is explained on analysis by the fact that when she lost the first baby the doctor told her to be on the outside (out of doors) as much as possible. Then when her second child came along by the undesired husband and forged another link to bind her to him, she developed a fear of being in the house. She wants to be under the same circumstances as she was when the first child died. She wants to be outdoors as that symbolizes freedom to her in relation to her undesired husband. On the surface, she worried because her husband commuted to New York and thought this was a terrible distance and was afraid he might be killed by the cars, this evidently being a defense reaction to ideas that she wished to be rid of him (such ideas not being acceptable to her personality).

The symptoms of this case, from a purely formal standpoint, show odd thoughts and actions with gradual deterioration of the mental organization and dilapidation of the personality. When the facts of the patient's life are carefully investigated and free associations are made, it is seen that all her peculiar utterances and eccentric acts refer back to a strong, central affective complex; the old wished-for lover and the unsatisfied longing for him in 
conflict with her present situation, in which she finds herself married to a man whom she had taken merely for conventional reasons to cover her quite incidental illegitimate pregnancy.

B. E. P., No. 73810.

Family History.-Complete for three generations. One maternal uncle seemed bright, but was a loafer and sponged on his family. Mother nervous disposition; worried over small things, but was easy going in larger matters.

Personal History.-Born in New York, 1890 ; early life entirely uneventful; seemed a perfectly normal child and began school at six and attended high school, but did not graduate. She was ordinarily intelligent, seemed interested in her work, liked to draw, but did not apply herself very well, and was left back in her classes a couple of times. Make up seemed quantitatively normal; qualitatively was easy going; always seemed ready to mingle with other people; was bright and jolly, but was never very much attracted by men or boys and had more girl friends than men friends. She associated with no one particular friend (girl) however. After puberty her disposition did not seem to change and even when she began to meet men more concretely later she did not seem to change particularly. After leaving school she stayed home and did the housework for a while, but never did very much and never seemed to go ahead and plan things, but what she did do seemed to be done well. As she approached the age of 20 she went outside to work and assisted with clerical work in an insurance office, where she appeared to be satisfactory, but was let go with a number of other girls when the office force was reduced and then took a position as a telephone operator. Her work was well done and she stopped working only two weeks previous to admission to Kings Park State Hospital. In December, 1913, while working in the telephone office, she began to have queer thoughts, which seemed to come on rather suddenly. She told her brother about these thoughts and wanted to know if that was the way you felt when you were in love, but did not give any definite information until a month later, when she said to him, "I am not just right; I have had peculiar feelings; there is a certain young man that $I$ have been having some thoughts about. I feel depressed. When his face is flushed, my face is also. One day when I was in the hall a girl said to me, "That man is nice; why don't you see what you can do about getting him?' Tell me, am I in love? Is that the way you feel?" Two days after this interview she stopped work, went home and conducted herself in an orderly fashion, but seemed preoccupied and walked up and down a great deal. A week later she became rather uncommunicative with her family and seemed sullen and ungracious when they spoke to her. Finally said, "There is something the matter with my head and I want to have it cleared up; my folks are watching me and won't let me out alone." She then made voluntary application for treatment and was admitted to Kings Park State Hospital February II, I9I4.

On Admission: States that she felt nervous and depressed without known reason; that her ears rang and at times she hears voices; peculiar 
thoughts come into her mind unbidden and exert a great influence over her conduct. Physically, complained of numbness in her hands and feet; otherwise neurologically negative. Mentally, general behavior was quiet, compliant and accessible. Inclined to be a little suspicious, but made a rather favorable impression on the whole. Stream of mental activity showed answers to questions relevant and coherent. Spontaneous production was normal in amount and content. Her mood was one of mild anxiety over her condition, but little real depression or tension. She could smile readily, yet at the same time did not appear particularly happy. At times was inclined to be a little impatient with those around her; emotional tone seems intact. Her trends were along lines of influence. She thinks she has been forced to move when a certain man came around and has been forced to think all sorts of thoughts, many on sexual lines, associated with visions. Immoral ideas have been intruded upon her. Thought a man in the office where she worked put her in a trance every time he came near her and that he controlled her movements. Visual hallucinations had occurred; she had heard distinct voices; also had smelled chloroform while in bed and tasted peculiar things in the food. Purely mental functions, such as orientation, memory and general grasp, were intact. She gave the impression of a person who recognized that her ideas were abnormal, and yet because of their intensity and the emotions that went with them had been unable to convince herself that they were entirely unusual, and in that sense clings to them, although asking for treatment.

An attempt to get at the underlying complexes in this case reveals the following:

As a child she seemed to have shown little out of the ordinary; she did not block or show marked resistance at any one point of her whole life and seemed to have developed along fairly normal lines without any very definite introversion. As she was approaching the age of 20 a young man attempted sexual intercourse with her, but she did not let him accomplish this, however. She did not seem to worry very much and in fact went calmly to bed afterwards and complained simply that she felt a little nervous and restless that night and could not sleep well. After that she went ahead with her usual plans and only when she fell in love with a man whom she actually wished to have and he did not propose did she begin to ruminate over the situation; sees his nude body exposed ; feels like proposing to him; hears his vioce in endearing terms and was conscious that she would be willing to do anything for him that he wanted her to, whether she were married to him or not.

Excerpts of her statements on free association show the following: 
288 TRANSLATION OF SYMPTOMS INTO THEIR MECHANISM [Oct.

I knew a young man; I was very fond of him and I thought he liked me. I had never had any actual sexual experience with men. At home I grew up with my brothers and sisters and we seemed to learn about these things quite naturally. Of course I saw pictures and statues and knew there was a difference (between men and women), but I never thought much about it. When I was 20 I was up in the Catskills and one time a young man attempted improper conduct with me and I repulsed him. I was always able to take care of myself, anyway; I didn't sleep much that night, but it didn't affect me except that it made me feel a distrust for men and I thought they only wanted you for one thing. I had no special ideal of men. I was working in an office as telephone operator; there were other men there and this young man I liked worked there. Christmas night (1913) I had felt very happy that day. I went to bed about ro o'clock, then a lot of thoughts came in upon me; I thought I noticed that I felt compelled to say things to other people, like the people I was making out policies for in the office. This feeling came like a thought that would sound in my head like a voice. This voice came particularly when this man was in front of me; it seemed as though he were putting thoughts into my headthoughts of him in relation to love and marriage and all that went with them, and later, incidental thoughts, such as go and get a drink of waterit seemed to me as though I felt that love were taking my senses away from me. This trance voice sometimes told me to do improper things to others. I began to mistrust the men in the office and felt that some of them had designs on me to make me bad. That Christmas I saw some visions-pictures of men in exposed conditions. I saw them in the daytime, right in the office and thought they were at the side of me. I also at such times heard a very distinct voice which just wanted to embarrass and bother me. I saw my lover in the vision-he exposed himself-I would be frightened and that's the way I knew something was the matter with me. I have had all the sensations that go with love; these happened when I was home in bed. I was sleeping with another person in reality, but he seemed to be near me just in spirit, but I had all the feelings. I had feelings that shot through me once, for two days in the office, they seemed like vibrations, perhaps more like electricity, all through my body. (They struck her sexual organs, but did not originate there.) I felt a fear and thought he was coming after me. This happened one day about the Ist of January, when I was at lunch with him. I answered his voice which asked for me and said, but not out loud, "you can't have me." I liked him and it seemed strange that I should say that he couldn't have me, because I had always been ready to do anything for him if he had asked me, whether we were married or not. He knew that I liked him, but he never tried to do anything detrimental to me in reality; but when I heard his voice or saw these things, he could have done anything with me. I had no distaste for him; there were lots of other little things. I liked purple and always wore a purple dress and one day he wore a purple tie and when I saw it I said, "When you are through with that tie, you can give it to me." I don't know what made me say that. (Disguised expres- 
sion of subconscious fetichism.) One day I was conversing with him and he said he didn't have enough money to get married on-I don't just know how the subject was brought up-and so he couldn't ask anyone to marry him, and I felt like saying, "I feel like asking you to marry me." (Projection of the wish in the form of conscious impulse which was restrained in this instance.)

This case represents essentially a badly managed situation in which the wish fulfilment could not be brought about in reality and the psychosis developed as a substituted reaction, characterized by symptoms representing the projection of internal ruminations. Whether readjustment is entirely possible is questionable, but the reason for her peculiar conduct is at least thus explained.

H. E. R., No. 40202.

Family History.-Complete for three generations. Mother insane; father very religious.

Personal History.-Born in Ohio in 1864; made the usual progress at school. Make up quantitatively normal; fond of entertainment, but worried rather easily. At the age of 19 married a printer and seemed an efficient housewife. At about the age of 33 she suffered a depression which was brought on by so-called domestic trouble and developed ideas of persecution. She became resistive, was mute and required tube-feeding and was treated in a sanitarium for three months and then left unimproved. Two months later she was admitted to a state hospital, where she remained for about a year. While there talked loudly; showed delusions of a religious nature; talked of the Lord taking her speech away and became mute. She improved and appeared to abandon her delusions and was finally discharged after a residence of nine months. She remained at home for II years and her husband considered her quite well in this interval. Then rather suddenly she became excited and expressed ideas of a religious nature. She was again admitted to a state hospital in May, 1909, and remained there until September, 19II, when she was discharged improved. She remained out for about two years and then began to act queerly, but was able to remain at home, looking after her household duties to a certain extent. Six weeks before coming here she witnessed an operation on her nephew for adenoids which greatly upset her and she began to react to hallucinations; imagined that some one was telling her to get away, so she wandered from home. This caused her commitment.

On admission to Kings Park State Hospital, November 19, 1913: Physically, fine intention tremor of tongue and fingers; otherwise negative. Mentally, was apparently laboring under some pressure of speech and seemed elated, showing a tendency to elaborate her answers. Trends are not very well systematized and show ideas of persecution, with auditory hallucinations. She laughed a great deal, but again would show no emotion when discussing such things as the death of her mother. Thought she had been poisoned and expressed queer ideas about not having had earthly parents, 
290 TRANSLATION OF SYMPTOMS INTO THEIR MECHANISM [Oct.

but having been placed on earth by God. She spoke about babies a great deal and of performing miracles. She continues to reside in the hospital unimproved.

On probing and after allowing the patient to make free associations and also by taking note of her spontaneous production for a considerable period of time, it is found that the affective factors in her life are as follows:

Her childhood seemed uneventful; she was always fond of entertainment and was greatly interested in her home life. Whether any change occurred at puberty we are unable to ascertain, and no definite period of introversion is demonstrable. She married a printer when fairly young and on the surface their married life seemed to be fairly successful. She never had any children. She brought out in her talk (referring to her husband) "that he was a poor (soft) fellow," then apparently to counterbalance this, consciously said, "to know him was to love him," and concerning his family said, "they were a lovable family, affectionate and loving; every Sunday they would sit down and sing a hymn before breakfast; loving and true and generous." Concerning children, said, "I would have liked to have had children and I heard a voice say "God will show them to you some day." She never had any children and said, "I know; I was told that some day God will show me the little ones that would have been born if $I$ had not been meddled with." (Uterus was curetted at the time of her first admission to a state hospital.) She had felt worried and depressed previous to this operation in February, I897, and following it seemed to become worse and developed her first psychosis. She followed her husband to business to satisfy herself that he was her husband (beginning of unreality complex), and soon after this made repeated attempts to drown herself in the bath tub; thought that her husband was not her husband but a spirit, and that God knew where her real husband was. Said "spiritual people put everything in my body and made it hard" (rubbing her abdomen-pregnancy complex). Thought the people around her were spirits; the nurses changed into her husband at times and the doctor knew all her thoughts.

The active psychosis subsided and after about in years developed again after having had a disagreement with a family who lived above them. She had had no children in the meantime and 
again made attempts on her life. Said " my husband and I lived so happy, only that woman (the woman who lived above her) came into the house and took my insides out." Talked with the Lord and thought that her husband was not her real husband. This idea led back to a complex developed in the patient by the fact that her husband had been named as co-respondent in a divorce suit shortly before this time.

Her wish for children was still denied. Evidently she felt that she was fighting an irreparable situation, and, being unable to readjust herself with the facts, developed a psychosis in which the idea of wish fulfilment was plainly expressed. At the time of her admission to Kings Park State Hospital November, 1913, she presented a florid delusional picture, in which the predominant idea was that "she was the baby replenisher of the earth," and at the same time justified the peculiarities of this delusion by saying " people followed and abused me all my life since I was a little baby - since God put me on earth-I was good, a little capable, they saw the spirit in me-I have an idea that it is nationalities, at times Irish. They didn't understand to be quiet and not to interfere with people. Little voices (baby) come from purgatory, God's voice speaking to His baby replenisher."

The psychosis advanced to the point where she lost contact with reality to a considerable extent, as shown by her ideas and also by her attitude. She now has found the fulfilment of her wish in partnership with God's plans. He tells her "I will never leave you, baby replenisher-my husband (who was unable to impregnate her) has taken on a new house and the woman who was supposed to live there was named Jesus Christ. I was next door-I thought I would never room with my husband again (she refused coitus with him on account of his supposed infidelity) you know what I mean and a little voice said 'you are to be God's baby replenisher' - I have had no intercourse with my husband since I was taken away four years ago. I never suspected my husband until these bad times, when the women were paying money and grabbing things (referring to husband's supposed infidelity). I don't like to listen to this ; it hardens the germ in me-little people that God gave me" (pregnancy complex).

The case illustrates a conflict involving sexual life and primitive instincts; wherein definite wishes were impossible of fulfil- 


\section{TRANSLATION OF SYMPTOMS INTO THEIR MECHANISM [Oct.}

ment and the reaction took the form of a retreat into a psychosis, where the wish was fulfilled in a satisfactory manner, but with great dilapidation of the surface personality.

M. C., No. 72564.

Family History.-Complete for three generations; mother irritable.

Personal History.-Born in Russia in 1886 and came to the United States when 2 years old. Attended school from 7 to 14 years and afterwards learned stenography; record good; never left back in her classes and learned easily. Make up, quantitatively normal; qualitatively irritable, rather inclined to keep by herself, or was at least not at all aggressive about going out with others, but would let them go to parties without her. As a child she played well with other children, but was excitable and highstrung and quick to take offense. Efficient as a stenographer. Puberty at 12; she felt a little more inclined to stay in the house after that. Married at 20; had a child a year later with a normal puerperium. Married life happy for five years; then her husband's business required him to be out at night and she was left alone a great deal, which made her nervous and she did not like it. Her father had died in the summer of 1912 and after this she began to have bad dreams. In November, 1912, she ran out in her night dress and telephoned for her husband to come home. Then she began to have periods when she would throw herself on the floor and cry and act peculiarly. She would get one of these attacks if she worked, because she always worked as if under pressure and moved around very fast. She would not say much during the attack, but would weep loudly and afterwards always felt quite depressed and flat. She did not like her motherin-law very much, but had no open trouble. About seven months later, in May, 1913, she developed indigestion, which grew worse; began to think she had a cancer in the stomach; did not want to eat, and about October I, 1913, rather suddenly became listless without any very definite upsetting factor and lost all interest in her home. When actually asleep she would think that she had not slept. Attempted suicide and became angry because she was watched and asked to be killed. Then following that developed the idea that her body was dead, and was admitted to Kings Park State Hospital, December I, rgr3. There her general attitude showed depression, but she was passive and compliant; spontaneous production was normal in amount and her replies to questions were relevant and coherent; showed a little tension and some agitation. Trends were all along ideas of bodily change with a mood of despair, believing that she will never get well. She showed the beginning of loss of contact and unreality syndrome in that she did not seem capable of experiencing pain and pleasure as she formerly did and things appeared changed. Pleasure left her unaffected. She seemed rather suggestive and said, "I thought I had ulcer of the stomach; I used to get these pains and a woman told me her husband died of the same thing and that gave me a terrible shock. I tried to keep my mind off it, but I used to get frightened when I thought of it." Later, when a physician gave her a physical examination, she came to the conclusion 
that everything about her was dead except her heart. This was because he turned round and whispered to her husband and said, "she will be in darkness (grave) in four months." There was a feeling like shocks of electricity in her genitals; this happened only recently. She has continued depressed and required tube-feeding. Emotional tone on the whole is intact and in accordance with her ideas, although she has become rather indifferent to her child and is able to discuss the fact that she could die and leave the baby to the care of the father without any extraordinary emotion and says, "what has to be, must be." Purely mental functions, such as orientation, grasp and the like, are intact.

On probing it is found that she seemed to be perfectly normal until puberty and then suffered a slight introversion with increased seclusiveness, which, however, did not prevent her from going ahead with her work in the world, finally marrying for conventional reasons. She has always been quite fond of her father. At the age of 15 she began to practise masturbation at the suggestion of a girl friend and practised the habit up to the time of her marriage. She performed it on herself up to the age of 18 , when she began going with the man she married. He used to place his hand upon her genitals, following which she obtained the same sensation and did not masturbate after that, although permitting him to do it. She married about a year after that, but did not have any extraordinary affection for her husband, but accepted the marriage in a purely conventional way. However, she did not find sexual relations disgusting and in a general way it may be said that her sexual adaptation to these concrete factors was pretty good. There was, however, some friction with the mother-in-law and the patient felt that she did not entirely approve of her. She did not seem to be wholly satisfied with her husband, but justified this to herself by saying that she feared that she was not a satisfactory wife to him. Finally, the husband was away from home a good deal at night and when left alone patient said she felt nervous and desired to masturbate, but did not do it. The flight from the house in her night dress in one of these struggles against masturbation probably represented a flight from temptation not acceptable to the personality. For this reason she went to the neighbors to telephone for her husband to come home. She was troubled with bad dreams from which she often woke up with fright. Said of the dreams, "I was nothing but hearses and in one dream I saw a crowd and they said that a young 
girl had died. I thought it was a woman, but I couldn't tell what she looked like-the people seemed to be saying it was a shame, she was so young and had to die. I seemed to be on the sidewalk looking at the hearses-my husband wasn't there."

It would appear that the dreamer was both an onlooker and the persona dramatis. Her burial symbolized a means of getting away from her husband and his family. Told to write her name and address, she began to write her maiden name. (Expression of subconscious affective complex in trivial ways.) She noticed the mistake as soon as she began and crossed the letters out and finished with her married name; remarked that she thought it was odd she should do such a thing. When asked to write her maiden name, showed much resistance and refused to do so. Later, developed marked unreality syndrome in which all things were changed; her husband does not care for her; her body is dead; her bowels do not move, etc. There were many ideas of unworthiness and self-renunciation which seemed to be an atonement machanism. This caused intense pre-occupation at all times.

This case is not complete, but, in the light of psychoanalytic experience and the literature on the subject, there is pretty conclusive evidence that her husband was not the sort of man she desired, and associated with this was his family, which was also distasteful. There is here an unsatisfied wish fulfilment and the psychosis represents an attempt to get away from an undesired situation and explains why she could talk about leaving her baby (the child of the undesired husband) or her own expected death without much emotion, because all this agreed with the mechanism of a plan to get her wish. Superficially her mood is one of depression, but essentially is one of dissatisfaction. In view of the fact that the psychosis is dependent on her marriage, a situation hard to change in actual life, the outlook must be clouded and the question of final readjustment will depend, not only upon the patient's attitude, but the husband's acceptance of facts as they are and the willingness of both to alter them if necessary. Certainly she is laboring under a strong affective conflict and even in her conscious life she endeavors to repress the complex because it is not acceptable to her personality. "I am trying to forget these things." The feeling of cancer of the stomach was simply a convenient hook upon which to hang all her ruminations about death, 
an incidental and acceptable idea to which was transferred the affect of the fundamental sex difficulty complex. Cancer and death symbolized a getting away from the man she did not want.

E. B., No. 72593.

Family History.-Complete for three generations. Paternal grandmother alcoholic. Maternal grandmother had epilepsy for threc years at about the age of 6r following a blow on the head. Father alcoholic, immoral and thought to be of inferior type. One brother died of paralysis at the age of 16, type unknown; no trauma; onset sudden; bilateral, involving legs and sphincters; not accompanied by pain; died in three weeks after onset.

Personal History.-Born in Pennsylvania in 1890 ; instrumental delivery. Never had any convulsions or severe illnesses; made a good school record. Make up, quantitatively, normal ; qualitatively, said to be sociable, but was stubborn and hard to control at home and later became wayward. After leaving school she lived with her parents on a farm. At the age of 16 they moved to New York, where she secured a position as telephone operator and was successful in it. She became infatuated with a coachman of a flashy type, who for four months called on her at her own home. Then the mother interfered, the daughter became enraged, bit her mother and decided to leave home and board with a friend of the family. It was after this move that she had illicit intercourse with the coachman, who refused to marry her, and she is believed to have practised perverted sexual acts with him. She continued these relations for four years and then became pregnant and an abortion was induced with resulting peritonitis. This was in the early part of I9II (two and a half years before admission). Following the abortion, she went to live with her mother and did not see the coachman. He is supposed to have filled the patient's mind with many rumors concerning her family. Following her breaking off with the coachman, the patient masturbated almost continually. She became very irritable and quick tempered, but all the time was apparently a successful telephone operator. She developed a strong dislike for her mother and for a certain man who boarded with the family, and stated that this man was alienating the affections of her mother. She kept a diary in which she used obscene language and applied immoral names to her mother and accused her of illicit practices. She finally struck this man with a pitcher, which led to her commitment. Her predominating idea seemed to be "a wrong to be righted" and she wrote to the President of the United States and other noted men for this reason.

Admitted to Kings Park State Hospital December 12, 1913. Appeared depressed; did not eat or sleep well; wept frequently; stated that a man living at her house had some sort of influence over her and keeps her uncomfortable and unhappy; believes this man is intimate with her mother. While she was carrying a pitcher, he stepped into the kitchen and she immediately lost control of herself and struck him over the head with it. Said that this man and her mother have shattered her ideals of life and driven her to foolish actions. 


\section{TRANSLATION OF SYMPTOMS INTO THEIR MECHANISM [Oct.}

Physically, well developed young woman; cold hands and feet; rectal fistula and infected umbilicus. Mentally, she was quiet, compliant, fairly accessible and showed no very odd reactions in her general behavior. Stream of talk was relevant and coherent. General mental attitude; a feeling of depression on account of her surroundings; has ideas of reference and a feeling of guilt. Admits living with this man for four years illicitly and having had an abortion performed. Said that this man told her tales concerning her mother; that she was not conducting herself in a proper way with the man boarder. Ascribes her outbursts of temper to injustice which has been done her and expresses resentment against the alienation of her mother's affections by this man. She has read a good deal and ruminated over rather abstract topics; lately the subject of eugenics has interested her a great deal and she has felt that she could never have healthy children, this again being a source of worry. Mental organization was intact; showed no memory gaps; orientation good; insight fair. Her personality was quite pleasant and she showed no compromising reactions for several days, and then quite suddenly attacked another patient absolutely without adequate cause, saying that she "did not like the ring of the other patient's laugh and that she would assault her so that she would not remember what she said." This she did and at the same time said, " now, maybe you will believe in God-call all your little ghosts around you to help you" (referring to ideas she had heard the other patient express). She said this patient's (Mrs. C.'s) talk reminded her of her brother's death. After that she got along very well for a couple of weeks, then attacked another patient, Mrs. J., threatening to kill her, saying, "last night she was trying to find out why I was here and it is none of her business." She quite calmly prepared to deliver an assault on Mrs. J., for which reason she was removed to another ward. Later she stated that Mrs. C. (the first patient whom she assaulted) used to look at her legs and from that she knew that she was reading her thoughts and that her look meant that she must overcome the ghost fear. About this time she became quite sure that she heard God's voice. "First a man's voice, then the gentle voice of God in contrast." After three months her interests had narrowed down and she constantly misinterpreted the actions of others. Feels that the doctors and others are unusually interested in her and displays affective reactions when certain names are mentioned to her, concerning whom she has elaborated along sexual lines. She cuts out pieces of poetry concerning the "Hidden Life," "Companionship," etc., showing a tendency to ruminate along vague abstract lines. She showed a good deal of blocking and marked amnesia for childhood experiences.

Free associations on the part of the patient bring out the following upon which her symptoms are based: There was evidently a good deal of conflict between the mother and father, the latter being alcoholic and immoral, which may have given the patient childish fancies of a disagreeable type. She said once that she 
had always been more or less irritable. She has ruminated from an early age over sexual matters and sexual realizations. These fancies increased following the beginning of menstruation and she recognized that she was unusually well developed for a girl of her age and rather better looking than the average. She was sure of this by the time she reached 15 years. At this time she fell in love with the boarder in the house, Mr. D. C., but he did not reciprocate. Then met another man, the coachman, concerning whom she had a quarrel with her mother, at which time she developed an exaggerated sense of anger and left the house to become the common law wife of this coachman. (This probably was something in the nature of a compensatory reaction, as she felt that Mr. C. D., the man whom she loved, did not care for her at that time.) After several years the coachman wished her to become a prostitute on the street for him. She became thoroughly disillusioned and returned to her home. In the meantime Mr. D. C. had continued to hold his charm for her, but on her taking up her residence with her mother she found him in rather compromising situations with her mother, for instance, being in her bedroom, but stated that she never saw him in an actual adulterous act. The situation at once aroused the ancient affect complex, this being the man she loved, whom she could not attract and who never had seemed to want her. She still loved him, but at the same time hated him not only for his making love in the abstract to another woman, but this hatred was intensified because the other woman was her own mother. She became depressed, contemplated suicide, but desisted at the last moment because she was afraid of what she might find in the next world. Then, while she was torn by these conflicts, one night Mr. D. C. came into the room where she was and she said, "it was a case of either hitting him or of throwing my arms around his neck and-I hit him." Contemporaneously Mr. D. C. had been throwing up to her the intimacies she had practised with the coachman and called her a bad name (which she consciously attributes as the reason why she threatened him with violence).

The present upset seems to be largely in the nature of difficulty in making adequate adjustment to an intolerable and yet unchangeable situation. She felt that Mr. D. C. would never love her; that he had ruined her mother; that by her own foolishness with an- 


\section{TRANSLATION OF SYMPTOMS INTO THEIR MECHANISM [Oct.}

other man she had lost her good looks and her prospect of marriage, and finally Mr. D. C., whom she loved (who was the person for her wish fulfilment), spurned her. She could now adjust herself to the situation no longer. It was for these reasons that, when little incidents, trifling in themselves, occurred, like Mr. D. C.'s coming into the room, she suddenly became assaultive and acted in a way seemingly out of proportion to the moment. But when the conflict is analyzed, it is seen that there was adequate reason for her conduct. Her ability to make further readjustment has been destroyed and as a result she sees meanings with personal reference in the acts of all people and shows a tendency to a vague scattered form of spontaneous thinking, speaking and writing, throughout which runs a sexual undercurrent. Recently wrote, " last night I had one of those wet dreams, result of going to bed too early, excess vitality in other words. I know you are shocked at me, but I can't tell these women doctors; it eats to the quick to talk about such things as that to one of your own sex."

J. C., No. 72048.

Family History.-Complete for three generations. Father alcoholic; sometimes talked queerly. Mother over-sensitive and nervous. One maternal cousin "over-active and destructive," was considered insane. One maternal uncle alcoholic. One sister died aged $3^{1 / 2}$ years with convulsions.

Personal History.-Born in 1892 in Italy, of peasant parentage, and came to America as an infant. Is said to have had little opportunity to go to school, but was dull when she went and was left back at least once. After leaving school she became a factory operator on collars and cuffs, making only small wages and is to be considered quantitatively inferior in makeup. Qualitatively she was seclusive, subject to the "blues" a good deal and seemed easily frightened. She drank wine occasionally with the family at meals. Seemed to get along fairly well in a general way until about the age of 19, when she began to grow more or less untidy in her habits; would stay in bed for days at a time and made no attempt to do any kind of work for eight months previous to her admission here. Her mood varied and at times she did some shouting and screaming and apparently was apprehensive of harm.

On admission to Kings Park State Hospital November 19, 1913, indifferent and apathetic, but had periods of excitement, when she would shout and scream, saying that she was " unable to control herself." Physically, neurologically negative. Mentally she was passive, apparently somewhat indifferent, but showed no very unusual reactions; seemed mildly interested in what was going on, but made no comments. Stream of mental activity; spontaneous production limited. Replies to questions were relevant and coherent; said she had been sick a long time. "All the doctors knew was 
that I was afraid of pain-I was afraid of their hurting me - they didn't know what was the matter." Again said, "I always thought of holy things -I didn't seem to be like I was before-now I don't know how I feel; I don't know what is going to happen." Showed no agitation and seemed quite resigned to her various fears and phobias. General mental attitude, ideas of fear of harm befalling her, fear of passing over water, and fear of going on the street. Mood on the whole, one of mild indifference. She seems unable to grasp the true affective relationship of things. Emotional tone could hardly be said to be intact; shows certain inconsistencies, as "I suffer a great deal in my mind" (and yet shows no especial affect while saying this). Trends were not well defined or systematized; she wished to stay in bed a great deal and was afraid of things in an indefinite way; could not at first describe her feelings. Orientation for time was defective, owing to inferiority ; for place and persons fair. Grasp somewhat impaired, but no great degree of deterioration could be said to exist, but there was defect in grasping events as they go along. Insight partial; efficiency impaired.

From the formal standpoint, this case presents little of interest. She gives one the impression of being simply inferior and rather stupid. On looking into the case from the standpoint of analysis, we find that as a child she soon learned that she was slow in doing things and began to feel nervous and afraid for fear of censure. She liked to stay at home better than going out and playing with others and the same has continued throughout her life. She felt much of the time as though she had the "blues" and always felt apprehensive and afraid. She is a devout Catholic and has had religious dreams since she was six years old. These dreams began before she learned to masturbate, but there always seemed to be something on her mind of a sinful nature and she feared she would lose her soul. (There is a period of childhood amnesia which could not be reached probably covering some early complex which may have been the antecedent for the masturbation habit, and the religious dreams were in reality subsequent, rather than prior, to the masturbation habit.) As she grew older, this fear of losing her soul continued and she went a great deal to confession, but did not get much good from it. Finally, when she grew old enough to work, she became so nervous that she could go to confession no longer. When she was about $\mathrm{I} 6$ she went to church on this account; she was suffering from "a very nervous strain;" suddenly she had what seemed to be an intense shock through her body and head. She said, "I used to go to the mis- 
sion church and the man there scared me; he used to talk about such terrible things-about judgment and such things-I had my mind on religion-I thought I ought to do the will of God and go to church-I had committed all sorts of sins against God." Also she had received some strong impression from a doctor early in life. She said she was always afraid of doctors. Said, "I was afraid of pain; I was afraid of their hurting me ( the doctors); I suffered terribly before-when I walked around the rooms; I felt so unnatural, so strange-like somebody suffers all the time and they can't get out of it-I was afraid some one was going to harm me and I was afraid when I passed over water I would get drowned-I was afraid of fire-that if the building got burned up I thought I would get burned up too-when I was 12 years old I was frightened by a man - he took me in a dark place; he just put his arms round me; he didn't do anything to me, but he held me tight, and when I started to scream he let me go."

Probing concerning her fear of doctors, she said, "when I was 9 years old the doctor made my vaccination, but he didn't hurt me-when I got big, about 15, I got afraid of doctors-I was afraid they would hurt me, torture me, cut my arms and legs off and make me suffer (apparently elaboration of infantile ruminations over vaccination). Her mother had whipped her because she had talked and laughed with boys when she was about I4. She had had visions. She saw the Blessed Virgin, who appeared once for a moment and then vanished; "she was dressed in blue and white and swords were in her heart (just as in the picture)."

It appears that she wished that God would forgive her because she was afraid she would die and lose her soul; because she had had bad thoughts about people and her own self (masturbation). She prayed about other things, such as to be delivered from stealing. She had practised masturbation since a child and knew it was wrong and the idea of stealing probably represented a transference of the affect to a more acceptable form of sinning than masturbation. She said she had masturbated ever since she was six years old. Concerning a dream she said, "I saw heaven and there was a bar as if heaven were barred and the Blessed Virgin talked to me. That was before I ever did anything and I dreamed of the infant Jesus, just as if he were calling me and I had a bad conscience." 


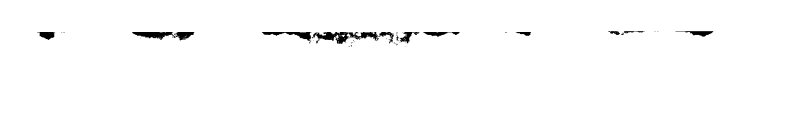

The patient is a childish, inferior type and the wish in the latent content of the dream is apparently the same as the wish in the manifest content as in the case of a normal child. The case shows the insight that can be gained into the conflicts of even rather inferior types of patients when we find them accessible and able to co-operate.

All of the preceding cases were those in which a formal diagnosis of " psychosis allied to dementia præcox" was made. Subsequent developments have seemed to justify this diagnosis, as the patients are showing more and more difficulty in making adjustments and consequently dilapidation of personality has begun. The next few cases are those which belong to a somewhat different type of constitutional reaction.

P. A. W., No. 73253.

Family History.-Complete for three generations. Maternal grandfather seemed a little queer and had a bad temper. Maternal grandmother was neurotic, but lived to an old age. Father was subject to attacks of the "blues"; was a fairly efficient coal salesman and was never considered insane. One brother lacks ability for concentration and cannot seem to apply himself to anything; does not want to work.

Personal History.-Born in Michigan in 1879 ; birth was instrumental. School record average; never left back. Make-up, quantitatively, normal; qualitatively, was idealistic; never contented in her home life; quite intellectual; worried over her own faults; was not anti-social and liked company. She was inclined to fret over small things, but was an efficient housewife. She married in I90I; had one child; living, none dead. Two miscarriages without special incident.

First Attack: Following childbirth in the spring of 1903 she became depressed about the first of May and throughout that summer thought she was eternally damned and wished to shoot herself; finally taken to a hospital in August, 1903, where her general mentation was clear, but she feared there was little hope for her on account of her thoughts of suicide. She worried and occasionally cried about her baby. Discharged November, 1903. "Acute melancholia ; recovered."

In the interval of ten years that has elapsed she was considered "nervous" and would get "worn out" and would have spells of "nervous weakness," during which she was all right mentally, but there was a good deal of lying down and she had to "push" herself to get through her work. However, she got along until November I, 1913, when a sneak thief got into the house when she was out and took a few things. On November 2, the first night after the burglary, she did not sleep and the second night after the theft she woke up with a nightmare, crying that her husband was being murdered by a burglar, but whom the burglar looked like she did not say. She calmed down and slept, but on the following day showed 
302 TRANSLATION OF SYMPTOMS INTO THEIR MECHANISM [Oct.

fluctuations on her moods; said she had been a drag on the family and should have been born dead. The family noticed she did not get into the spirit of Christmas (1913) very much and on January I, 1914, she began to speak of thought difficulty and seemed preoccupied. She thought of suicide and once got hold of an old revolver and thought of having it fixed up to kill herself; later thought of going down to the ferry and jumping into the water; then rather suddenly came to the conclusion that the country would be the best place for her (away from her city home). She thereupon went to a suburb, but said she was too near home; did not think it was far enough away, and for this peculiar reason returned home unexpectedly about January 15 and started to do her housework. Then suddenly packed her trunk and arranged with her husband to go far up the country. The day for her departure came, but when he met her downtown to put her on the train he found her much upset and sent her to her mother's home. She said she would not go on with the trip. "I am not fit for anything; I am desperate." She was then committed.

Admitted to Kings Park State Hospital January 27, 1914. She was depressed and worried over her condition. She realized her inability to read or to hold her mind on employment; fears she will never recover; becomes easily fatigued and contemplated suicide.

On admission, physically, well developed; neurologically, negative. Mentally, general behavior was quiet and compliant ; appeared depressed and her general activities were slowed down; showed a slight degree of initial lag in speaking and her voice was low. Stream of mental activity; spontaneous production reduced; answers to questions relevant and coherent; shows considerable elaboration along retrospective lines. While telling her story she showed a certain amount of tension; rocked back and forth in the chair; clasped her hands together; seemed somewhat agitated along with the depression, all of which was concentrated around a feeling of precordial distress. General mental attitude is a feeling of depression and hopelessness which she attributes to a burning sensation in her chest. This causes her to feel weak and discouraged. Her trends were not at all definite. No hallucinations. Purely mental functions, such as orientation, memory, and grasp, are unimpaired. She complained of a feeling of difficulty in fixation, yet recalled all important events. No deterioration. Insight good. Judgment on the whole situation satisfactory; no dilapidation of personality. On the formal side she still shows depression, retardation, general slowing, initial lag in utterance. No bizarre acts or ideas.

Free associations bring out the following:

My father was subject to attacks of the "blues," but he never suffered from any nervous diseases otherwise. His mother was left a widow before he was born and she thinks this accounts for his melancholy disposition. "He became depressed shortly after he was married-I have read a good deal about such things. My mother is of a highly strung temperament." Her father was a 
French-Canadian and perhaps not entirely normal. He had a bad temper. "My youngest brother, who is wayward, is said to resemble this maternal grandfather of French-Canadian birth." She told of her childhood experiences, in which nothing very definite came out. Said, " when I was ill before I used to play and dance and sing and do everything that I ever did, except that I used to think I was weak, and then when my little boy was born with a cleft palate I used to think it was a punishment for me and I would cry a good deal."

For a long time the patient showed considerable resistance, but it was finally brought out that when she was 14 years old she fell in love with a man of a certain type of physical build who brought her much candy and many flowers, and as she grew up she continued to ruminate over him constantly and set him up as her ideal. However, he was of a lower class intellectually than she desired to marry. For conventional reasons she did not marry him and eventually married her present husband. Mr. W. was of a cold disposition, quite intellectual and highly efficient in a business way, but he never made any fuss over the patient; never seemed to know whether she was around or not and she missed the endearments which the other man had given her. Her love for the first man continued to linger steadfastly in her head and it was this submerged feeling of disloyalty to Mr. W. that made her think it was a punishment put upon her when her little boy was born with a cleft palate; all of which was undoubtedly the cause of her first attack of depression a year after marriage. She evidently made a readjustment to the situation and got along pretty well with varying success and fluctuating moods until October I, I912, when a workman came to her house and the patient was surprised to find herself noticing him. He resembled her early lover. Amorous thoughts arose " concerning him." She began to feel physically weak and tired out almost immediately, but there had been no concrete incident at this time. This in reality was the onset of her present psychosis. During the year following this accidental resurrection of her affect complex she had attacks of physical weakness and periods of depression with increasing inability to concentrate her mind. This increased to such an extent that she could not read ordinary newspapers. Finally, apparently quite accidentally, the workman returned in 
304 TRANSLATION OF SYMPTOMS INTO THEIR MECHANISM [Oct.

December, 1913, and evidently finding her in a responsive mood, spoke of a picture he saw of herself on the table and apparently started up a flirtation with her. She allowed him to put his arms around her and kiss her and she put her hand on his head. Later in the day she realized the situation in which she had placed herself and told him she was sorry she had done this and took the entire blame on herself. He asked her if he might write to her and she said " no," and that "she would never write to him." The workman whom she met in 1912 and again in 1913 brought to the surface the complex connected with her original lover, on account of his "sweet ways," which had evidently made a very strong impression on her in her early girlhood. Consciously the patient makes vehement defense of (her husband) Mr. W.'s moral and intellectual characteristics, but all her ruminations are occupied by the form and features and sayings of this physical ideal with whom she is in love. However, this flirtation with a workman was a thing intolerable to the patient's rather prim personality, the content of whose manifest consciousness was largely along churchly and conventional lines. The affect of the intolerable complex she subconsciously transferred to the complex of her son's health and she began to worry about him. This son is now ro years old and was born with a cleft palate, his father being Mr. W. The weakly, deformed child was associated with the cold (subconsciously), unloved husband and it is significant that when the baby was born the patient "wished it would die, as well as herself," probably because it represented an imperfect, undesired thing which separated her all the more from her first love. She states that she would never have married the first man at any time of her life, because he was uncouth; however, it is readily seen from the incident of the workman that this wish has always been awaiting fulfilment and was speedily dramatized when given an opportunity. She says now that she feels that she is slipping away from her family and fears that they will lose track of her. She admits having had a desire to go to the country, but does not understand why she should have been so "finicky" in her choice of a location; but it would seem that all these apparently trivial incidents symbolize $a$ wish to get away from her husband, for whom she does not really care. In addition to this complex, she states that she was never well understood by her 
mother, but always had a great affection for her father. At any rate the conflict that the patient has been forced to contend with has been such that she has never obtained any real satisfaction out of life. Three years ago, she felt temporarily uplifted when she joined the church, but this did not last long. Evidently this inefficient effort at sublimation was ineffectual. The depression is along rather natural lines and consciously represents a mechanism of atonement (for allowing herself to fulfil her wishes in connection with several men, which she knew was not loyal to her husband, whom she respected as an intellectual man, but who did not appeal to her primitive instincts).

L. N., No. 69886.

Family History.-Complete for three generations. Father said to be " melancholy at times" and alcoholic. Mother mildly alcoholic, but cheerful disposition. One paternal uncle, periods of depression.

Personal History.-Born in New York in 1863; early childhood uneventful; make-up, quantitatively, normal; qualitatively, social type; liked to mingle with others. She was tractable, even-tempered and agreeable. Obtained a common-school education; was bright and never left back in her class. After leaving school has worked continuously as a fur operator, making about $\$ 12.00$ a week. Puberty attained without marked change of character. At 16 she had a love affair with a man with whom she was intimate, and upon his refusal to marry her she became nervous and depressed and was committed for the first time to a state hospital, where she remained for about two years. After making an apparent recovery she returned to her work, changed her religion from Protestant to Catholic, and seemed to get along pretty well for about eight years, when she was again admitted to a state hospital at the age of 25. At this time she showed depression and ruminated a great deal over her former love affair. She remained in the hospital for about a year and seemed to have made a recovery, as she took up her work and remained out for about five years, when she was re-admitted, again suffering from a depression. Said evil spirits haunted her; thought her soul was lost; voices called her names. She gradually improved and was again discharged three years following admission. She remained well for 17 years, when, after collecting for the church on a very warm day, she rather suddenly became depressed and was admitted to another state hospital, where she remained only two months and was then paroled. She seemed perfectly normal to her friends for six months and worked as well as ever at her usual wages. Nevertheless, she was exceedingly conscientious and worried a great deal if she missed going to work. Just previous to her fifth attack she took a little gin as she had dysmenorrhœa, a thing that she had quite often at her menstrual periods. Feeling a little restless she went in February, 1914, to Philadelphia to visit some friends, who were in the habit of serving beer at meals. Here 
on one occasion she drank three glasses consecutively and began to worry over this. She soon began to show ideas along depressed lines, fearing that her soul was lost; heard the voices of dead persons and thought that at times she could hear God's voice talking to her, telling her to repent, etc.

On admission to Kings Park State Hospital, physically, she showed tremor of the facial muscles, tongue, and fingers; left pupil reacted rather poorly to light; knee jerks exaggerated; troubled with headaches. Mentally, her general behavior showed depression, although she answered questions in an ordinary tone of voice and appeared interested in what was going on around her. Stream of mental activity; spontaneous production reduced; replies to questions relevant and coherent; no very great tension. General attitude, characterized by ideas of depression, feeling that she had disgraced herself in the eyes of her friends by drinking three glasses of beer at one time and reproaches herself for many minor acts in the nature of sins. Especially reproaches herself for having watched two dogs copulating. She had all sorts of religious thoughts and developed states in which she seemed to be passing through obscene scenes as if "impersonating Madame $\mathrm{X}$, the Blind Girl," and others. She said, "I had been reading these books and I think I had been going through those parts too deeply. I was in bed and it seemed to be a positive reality. I didn't want to open my eyes and it seemed as though I were groping about in the dark. It was just like a play and it seemed as though my friend were there and she was shocked at the way I was acting, and if it were true, I myself would certainly be shocked." Has heard the voice of a man whom she formerly knew; also heard voices of angels and others. She developed what was analogous to scenic hallucinations while lying in bed and saw all sorts of dramas enacted in front of her in which she herself was often one of the actors. Frequently at such times she would smell sulphur. She also thought her eyes were "pieces of glass, as if they were not natural at all" (tendency to the development of unreality syndrome). Mental organism essentially intact; no deterioration; occasionally spontaneously complains of thought difficulty. Says, "I can't understand when this comes over me. At times it is hard for me to think." Insight good; judgment on the whole situation good.

Investigation of this case along lines of free association shows that the essential factor in her life and the one over which she has constantly brooded for 34 years is this:

She had been reared as a Protestant and at the age of 16 she fell in love with a man and had sexual relations with him; he then refused to marry her. He was a Catholic and divorced and as such was excommunicated from the church, but she as a Protestant had not been deterred from wanting to marry him on account of his excommunication. However, when he refused to marry her (when she could not get her wish fulfilment) she became de- 
pressed and after her recovery she herself became a Catholic. She did not consciously realize that this prevented her from ever becoming lawfully married to him (with the consent of the church). In doing this she developed a sense of atonement, an effort at making the thing right, $i$. $e$., doing a form of penance for her early illicit intimacy with him by thus placing herself forever out of his reach. She never married and her work as a fur operator kept her life restricted. She had no general outlet for her libido, but sublimated this more or less successfully by excessive zeal in church work. This substitution was not always adequate, and she consciously developed depressions, during which the buried irritative affect complex always came to the surface. She felt that she had done something for which her soul would be lost and all her ideas were along lines of religious recompense. After the age of 30 she seemed to have found the means of almost permanent adjustment, but with the onset of the involution period and the physiological cutting off of the libido, she found that life held less prospect than ever and at once the old conflict returned. All of this being upon a subject displeasing to the personality and which has been more or less buried, the depression is consciously hung upon the trivial incident of having disgraced herself in the eyes of her friends by drinking three glasses of beer at one sitting and also for having watched two dogs copulating. (The association here to her own case is obvious.)

By this year the constant presence of this irritative complex had shown a tendency to seriously undermine the personality and she speaks of things in a way that shows she has a tendency to get out of contact with the world, i. e., feeling of bodily change when her eyes were glass and things looked different when she felt that way. It would appear that the scenic hallucinations were vividly projected ruminations on the lines of her own wishes. When she would lie in bed and allow her fancy to roam unrestrained she would see herself in the role of a beautiful and attractive woman, who at the same time committed more or less sexual indiscretions; at the same time realizing consciously that " to conceive of herself taking part in such orgies was quite unthinkable." (She never was particularly attractive physically, and her charms were not strong enough to hold the man she loved and who later spurned her.) The auditory hallucinations were always of the voice of the 
308 TRANSLATION OF SYMPTOMS INTO THEIR MECHANISM [Oct.

man with whom she had been intimate. Regarding her dreams, she says "I dreamed I was going on a long journey and every time I woke up I would see a different scene-it is so vague-I have been dreaming that for years-sometimes I would feel happy and sometimes I would feel sad and I would make other people the same way. I thought I was falling quite a distance and then I would wake and I would seem to be so frightened " (showing the affective value of the submerged complex). She would dream of knives and had a fear of being killed in that way, which she explained consciously by saying, "you hear so much about the 'Black Hand' and I have even felt as though I was trying to aid somebody to stop that." The man she was intimate with was not an Italian, but this association refers to an Italian who wished to make love to her, but she would have nothing to do with him and with whom she never had any relations. The association here seems simply incidental. She dreams of snakes. Said, "I thought I was dreaming about reptiles all about me, but it seemed as if I had power to ward them off " (here probably associated with the incident with the Italian whom she repulsed as well as including primarily the first accepted lover).

The life history of this patient upon analysis shows quite conclusively that after the unfortunate affair with the early lover her many depressions are simply reactions to her suppressed complex which she has never been able to permanently sublimate and which after many years latency developed again at the involution period. To all her reactions, however, there is a marked atonement mechanism, which rationalizes the mental situation to her conscious personality.

These cases belong essentially to the group of constitutional depressions. Upon the formal side the outlook is good for recovery. From the psycho-analytic side, the prognosis is somewhat clouded, as we have found that the essential in each was due to an irremedial situation. The disturbing affect complex cannot be entirely sublimated by the patient, but it may be robbed of the greater part of its dynamic value by thorough and vigorous ventilation. This has been done and L. N. has long since returned home seemingly entirely normal. P. A. W. is still somewhat depressed and has failed physically to some extent. 